International Journal of Public Finance
E-ISSN: $2548-0499 \quad$ DOI: $10.30927 /$ ijpf.325421
Vol./Cilt: 2 | Issue/Sayı: 1 | (2017), pp. 1 - 6
journal homepage: http://dergipark.gov.tr/ijpf

\title{
The Remission of Tax Penalties and Its Effectiveness in Turkey
}

\author{
Fatma TAŞ ${ }^{1}$
}

\section{ARTICLE INFO \\ Received: 01.07.2017 \\ Received in revised \\ form: 01.08.2017 \\ Accepted: 08.08.2017 \\ Available online: \\ 15.08.2017 \\ JEL classification: \\ $\mathrm{K} 34, \mathrm{H} 26, \mathrm{~K} 14$}

\section{Keywords:}

Remission in Tax

Penalties, Tax

Disagreements, Tax

Penalties

\begin{abstract}
A B S T R A C T
Various methods have developed for resolving disagreements arising between the tax administrations and taxpayers. One of them is also remission in tax penalties. This method, if the fulfillment of the conditions set by the law is to ensure reduction of tax penalties.

Located the settlement our tax system, providing more opportunities for taxpayers compared to the method remission in tax penalties. Therefore, remission in tax penalties, it has become a way to apply for the remaining penalties outside the method of settlement.

It is necessary to make some changes in the remission method in penalties for solving this problem. It can be in two ways: To repeal is the first of these. Second, it can only be applied to for penalties the remaining outside the scope of the settlement.
\end{abstract}

\section{Introduction}

Taxation relationship causes a conflict of interest between the government and taxpayers. Naturally, the tax administration seeks to collect more taxes. Conversely, the taxpayers want to pay taxes as little as possible. This situation makes inevitable the disagreements between the two sides of taxation. This disagreement arises on many issues including tax penalties.

"The justification for tax penalties would appear to turn on what motivates taxpayers to comply with their tax obligations" (Doran, 2009: 111). "The legal and economics literature conventionally assume that the relationship is purely instrumental: the function of tax penalties is sole to support tax compliance" (Doran, 2009: 160).

The disagreements between the tax administration and taxpayers are mostly resolved by judicial authorities. This situation leads to loss of time and labor for both

\footnotetext{
${ }^{1}$ Assoc. Prof., Gazi University, fatma.tas@gazi.edu.tr
} 
sides. To avoid this, the idea of disagreements to be resolved in the administrative phase has been proposed.

"The taxpayer must never allow himself to be a victim of justice. The only way to ensure that this happens is if the taxpayer knows his rights in a conflict situation with the revenue authorities and is aware of the pleas, defences or "extenuating circumstances" which may be advanced to mitigate any penalty imposed." (Goldswain, 2003: v)

In our tax system, there are some methods to provide solutions to tax disagreements at the administrative stage. One of these is the remission of the penalties. It serves the purpose to collect penalties within a short time.

This study will focus on the application and effectiveness of the remission of tax penalties.

\section{Remission of Tax Penalties}

The reason for remission applied to tax penalties is to recover from a long judicial process both tax administration and taxpayers. It can also encourage taxpayers to the payment of taxes in a short time (Mutluer, 1979: 231).

The remission of tax penalties provides a discount in payment of monetary penalties. There are some conditions to benefit from this opportunity. When the conditions are met, the penalty remissions are applied. Thus, the government will be collected penalties in a short time. At the same time, the taxpayer is released from a portion of the penalties (Kocahanoğlu, 1978: 105-106).

\subsection{The Scope of Remission of Tax Penalties}

There is no limitation concerning tax types for the remission of tax penalties. Taxpayers and fined persons can apply for the remission of tax penalties for all type of taxes which are covered by Tax Procedure Law in Turkey.

This method covers all penalties related to taxes. The tax penalties can be or not depend to tax. Also, due to of tax evasion penalty it is possible to benefit from the remission (Şenyüz, 2016: 265).

\subsection{Terms and Conditions of Remission}

There are some conditions of the benefit from remission payment. These conditions are to avoid litigation for taxes and tax penalties, to make a request within the term of litigation, to pay taxes and the penalty remain after remission within legal time. 


\subsubsection{Avoidance of Litigation}

If taxpayers to sue for penalties and taxes they do not benefit from remission payment. The main purpose of the remission is to end the disagreement quickly. Litigation is contrary to the purpose of the remission. If the dispute has already been brought before the tax court, the litigation must be withdrawn the lawsuit within the application period (Şenyüz, 2016: 268) (Kızılot-Kızılot, 2011: 273).

\subsubsection{Making Application in the Time}

The second condition to benefit from the remission of penalties is made payment at attempt to apply to the relevant tax authorities within the period of litigation. The application period is 30 days from the receipt of the notification. If the dispute has already been brought before the tax court, the litigation must be withdrawn the lawsuit within the 30 days (Şenyüz, 2016: 267-268).

\subsubsection{Payment the Tax Penalties within the Period}

Another condition of the opportunity to benefit from the remission penalties is to pay within the period specified in the Tax Procedure Law in Turkey. The payment amount is consisting all taxes and the remaining portion after remission of penalties.

The maturity to the payment of tax penalties is a month from the end of the period of application. If the taxpayer gives a guarantee for the payment, it can pay within three months from the maturity date of payment. When the payment is not done in the time, it will void the remission (Şenyüz, 2016: 269) (Kızılot-Kızılot, 2011: 275).

\subsection{Remission Rates}

The remission rates are different depending on the types of tax penalties. The discount rate to be applied for the loss of tax penalty is $1 / 2$. This rate is only applied in the case of processing the misdemeanor of the taxpayer for the first time. In other words, this rate is applied only one time for each taxpayer. This rate is not associated with the type of tax, the taxpayer is related with its own. So, this discount rate is only applied one time to the taxpayer during life.

If the penalty for two or more tax types is given, how the application will be? If the taxpayer demand for the remission of penalties at the same time, this rate will apply (Şenyüz, 2016: 266). The rate of $1 / 3$ will be applied for subsequent misdemeanors.

The remission is applied to all irregularities (general or specific) which connected to tax or not. The rate of remission for irregularities is $1 / 3$.

If the monetary penalties increase due to recidivism, the remission is applied to the part of increased amount (Edizdoğan, Taş, Çelikkaya, 2007: 224). 


\section{The Problem of Effectiveness}

Determining the effectiveness of the method of remission requires knowledge of the data. Regular data are not available about the number of taxpayers who benefited from this method. In other words, it is not possible to use numerical data connected with this method.

However, some information can be obtained by comparing with the settlement about the functionality of this method.

\subsection{Reconciliation and the Remission of Tax Penalties}

Reconciliation is the most common way for settlement disputes in Turkish tax law. Taxpayer and members of the commission made to negotiate for taxes and penalties in the reconciliation. If the taxpayers and the commission agreed to negotiate and reconciliation is achieved, disputes are solved.

The main differences between remission by way of reconciliation can be summarized as follows:

- In the reconciliation method, it is also possible to ask for a remission amounting to tax. In contrast, taxes are outside the scope of reducing in the method of remission.

- There is the legal limit for the discount in the reconciliation method. In the remission method, discount rates are determined by law (Karakoç, 2014: 3655). When to use reconciliation method it is possible to gain discount more than the remission method. This detection refers to the results of the application.

- When to use reconciliation there is a possibility to make a statement about the dispute to the members of the commission. There is not a similar possibility at the other methods.

- The remission method covers all monetary tax penalties. The reconciliation does not cover the penalties due to tax evasion.

\subsection{Relevant Findings}

We will explain our findings according to our observations in the application. Because reliable data is not related to the remission method. It is deleted almost all of the penalties in the settlement process in practice. Deletion rate is recorded as 90 percent.

In some cases, the tax reduction is made too in the settlement method. Besides, the penalty can be removed completely considering the events in the settlement method.

There is not a risk for taxpayers when to demand the reconciliation. If agreement cannot be achieved, taxpayers can go to court. 
Taxpayers who applied monetary penalties due to tax evasion cannot use the reconciliation. These taxpayers can apply for the remission of penalties.

We cannot say that the remission method is effective when all things considered. The existence of the reconciliation method is hampering to demand on the method of remission in penalties.

\section{Conclusion}

Various methods for resolving disputes arising between the tax administrations and taxpayers have been developed. One of these is the method of remission in tax penalties. We cannot say that the remission method is effective when considering practical results.

The most important reason of this is the reconciliation provides more possibilities to taxpayers compared to the remission in penalties method. There are no quantitative data on the subject. However, the application results confirm this observation. Therefore, it has already become a way of penalty can be applied only for the rest of the remission of penalties outside the scope of the reconciliation.

Systematic integrity is required to make some changes in the method of remission in tax penalties. This can be done in two ways: The first and radical of these are removed from the law of the method.

Second, it can only apply to for penalties the remaining outside the scope of the reconciliation. Thus, the confusion in mind of taxpayers will be eliminated. 


\section{References}

Doran, Michael (2009). "Tax Penalties and Tax Compliance", Harvard Journal on Legislation, Vol. 46.

Edizdoğan, Nihat \& Taş, Metin \& Çelikkaya, Ali (2007). Vergi Ceza ve Yargılama Hukuku, Bursa: Ekin Kitabevi.

Goldswain, George K (2003). "Remission of Penalties in Income Tax Matters", Master Thesis, University Of South Africa.

Karakoç, Yusuf (2014). "Vergi Cezası Anlaşmazlıklarının Çözüm Yollarından Cezalarda Indirim Müessesesi", Dokuz Eylül Üniversitesi Hukuk Fakültesi Dergisi, 2014/1, pp. 3637-3739.

Kızılot, Şükrü \& Kızılot, Zuhal (2011). Kaçakçılık Suçları ve Naylon Fatura, Ankara: Yaklaşım Yayınları.

Kocahanoğlu, Osman Selim (1978). "Vergi Cezalarında Indirme Prensibi ve Uygulama Sorunları", Vergi Sorunları Dergisi, 1978/1, pp. 105-106.

Mutluer, Kamil (1979). Vergi Ceza Hukuku, Eskişehir: E. İktisadi ve Ticari illimler Akademisi Yayını.

Şenyüz, Doğan (2016). Vergi Ceza Hukuku, 9. Baskı, Bursa: Ekin Kitabevi. 